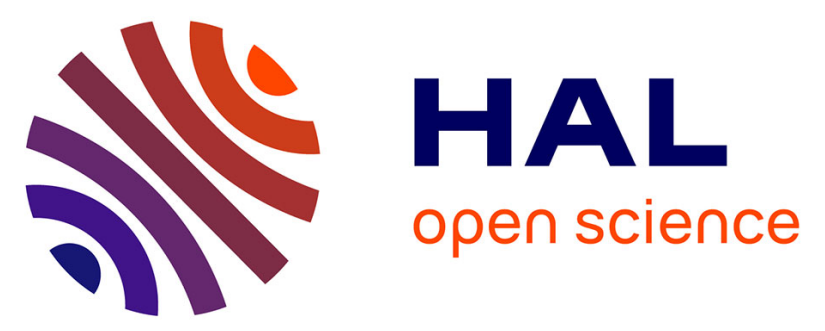

\title{
The End of a Hundred-Year-Old Archaeological Riddle: First Dating of the Columns Tomb of Kumbi Saleh (Mauritania)
}

Chloé Capel, Antoine Zazzo, Jean Polet, Jean-François Saliège

\section{- To cite this version:}

Chloé Capel, Antoine Zazzo, Jean Polet, Jean-François Saliège. The End of a Hundred-Year-Old Archaeological Riddle: First Dating of the Columns Tomb of Kumbi Saleh (Mauritania). Radiocarbon, 2015, 57 (1), pp.65 - 75. 10.2458/azu_rc.57.18112 . halshs-01454893

\section{HAL Id: halshs-01454893 \\ https://shs.hal.science/halshs-01454893}

Submitted on 12 Mar 2017

HAL is a multi-disciplinary open access archive for the deposit and dissemination of scientific research documents, whether they are published or not. The documents may come from teaching and research institutions in France or abroad, or from public or private research centers.
L'archive ouverte pluridisciplinaire HAL, est destinée au dépôt et à la diffusion de documents scientifiques de niveau recherche, publiés ou non, émanant des établissements d'enseignement et de recherche français ou étrangers, des laboratoires publics ou privés. 


\section{Radiocarbon}

An International Journal of Cosmogenic Isotope Research

VOLUME 57 / NUMBER 1 / 2015

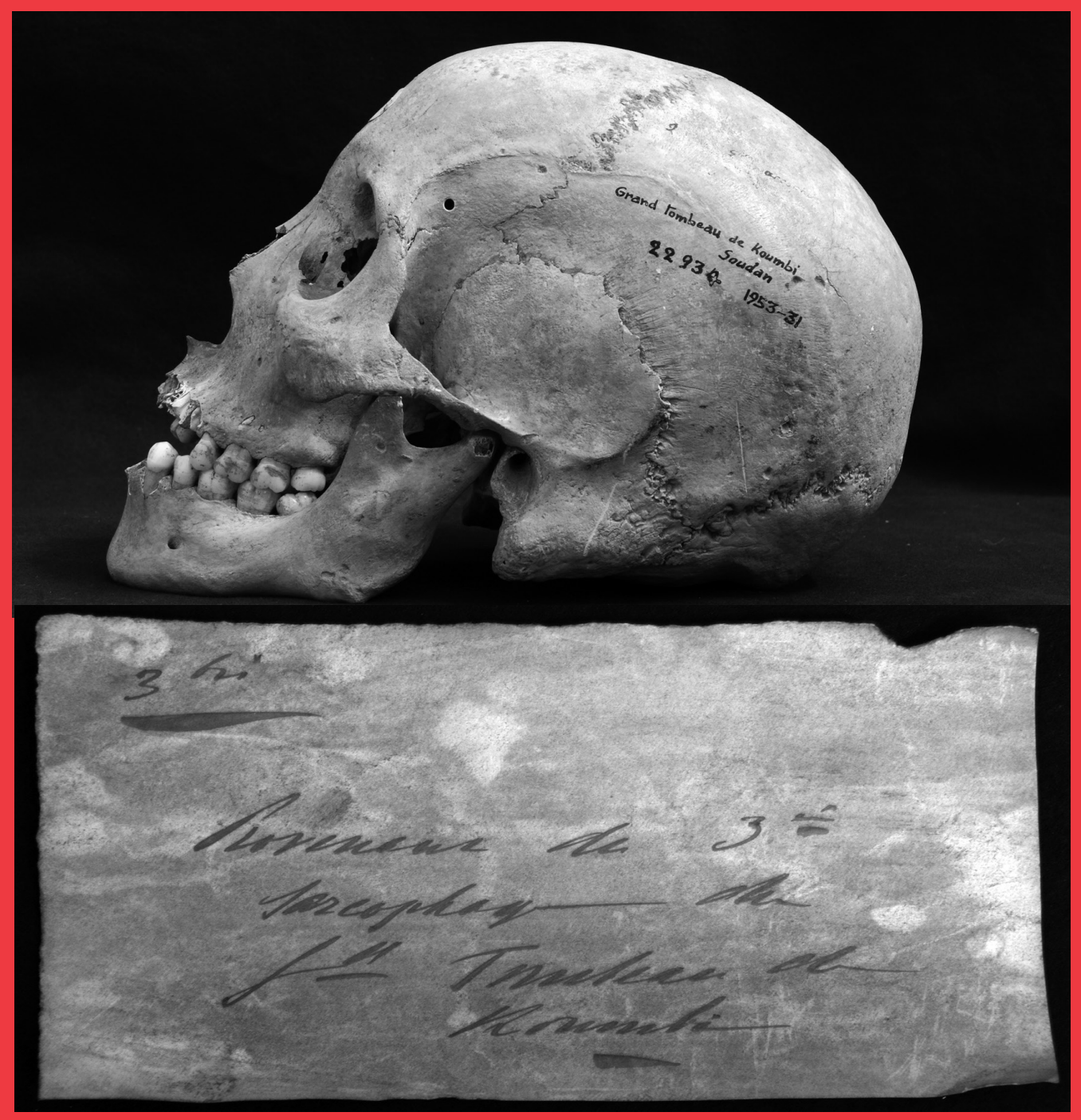

In this issue: C Capel et al. "The End of a Hundred-Year-Old Archaeological Riddle: First Dating of the Columns Tomb of Kumbi Saleh (Mauritania)" 


\title{
THE END OF A HUNDRED-YEAR-OLD ARCHAEOLOGICAL RIDDLE: FIRST DATING OF THE COLUMNS TOMB OF KUMBI SALEH (MAURITANIA)
}

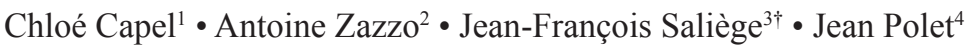

\begin{abstract}
One century after its discovery, the Columns Tomb of Kumbi Saleh (Mauritania) remains an archaeological riddle. Since 1914, six field programs have been successively carried out at the medieval urban site of Kumbi Saleh, which now is commonly identified as Ghana. The latter was the famous capital city of the medieval West African state, which controlled the gold mines of West Africa and was involved in the gold trade with North Africa and the Mediterranean Basin. However, interpretation of the tomb, the largest structure from the necropolis, is still an issue as its dating itself has never been firmly established. As a consequence, scholars have usually referred to an unsatisfactory timeframe spanning 1000 years. The study of this monument was recently resumed, motivated by the rediscovery of bones collected in the tomb in 1914 and stored at the Musée de l'Homme (Paris, France). AMS radiocarbon dating of the bone and tooth apatite fraction of three skulls demonstrates that the three individuals occupying the main vault of the tomb died between the end of the 11th century and the 12th century, precisely at the time of expansion of the Muslim Almoravid movement south of Sahara.
\end{abstract}

\section{INTRODUCTION}

\section{A Century of Fieldwork at Kumbi Saleh: Historiographical Assessment}

In March 1914, the French explorer Albert Bonnel de Mézières discovered the site of Kumbi Saleh in southeastern Mauritania (Hodh). This event was a significant and enduring milestone of archaeological research concerning the great West African empires, a set of powerful political entities spread out along the Sahelian belt, contemporary with the European and Islamic Middle Ages. The association of Kumbi Saleh with the capital city of the "empire" of Ghana, one of these notorious "West African empires," was immediate, though already hotly debated. According to medieval Arab geographies, where several of these "empires" are mentioned, Ghana was deemed to control the gold mines of West Africa and then became of the most powerful states in the region, between the 8th and 11th centuries. Involved in the lucrative trade of the precious metal with Maghreb and the Mediterranean Basin through North African merchants, Ghana established early contacts with Islam. Its capital was thought to include a substantial Muslim population, mainly of North African origin, confined in a special district, in fact a fully fledged city, out of the royal compound and local town (Description 328; De Slane 1913). The discovery of Kumbi Saleh in the spring of 1914 sparked the early 20th century intense discussions about the location of this dual town of Ghana (Triaud 1999:250). The brief report of Bonnel de Mézières (1923:232-43), described a large archaeological urban area until then completely unknown. A 10-m-high tell, which dominates the surrounding plain, represents the main settlement and contains numerous masonry buildings, including a great mosque. Close to this tell, Bonnel identified many remains scattered about, as tumuli, walls, enclosures, and isolated buildings. He also referred to two large cemeteries, located on either side of the archaeological tell, and called particular attention to a building erected on top of a hill that he referred to as the "Great Tomb" (Figure 1). This structure, immediately considered as the most important monument in the western necropolis, crystallized Bonnel's enthusiasm. He began with the opening of the inner vault and described it in his 1923 article, though he did not include a photograph or a sketch of the tomb's interior layout. In the absence of known personal fieldwork archives, this article is the best source of information available on the inner layout of the vault of the Great Tomb, which is now totally destroyed.

1. Université Paris 1 Panthéon-Sorbonne - Ecole doctorale d'Archéologie, Institut d'Art et d'Archéologie, 3 rue Michelet, 75006 Paris, France. Email: chloe.capel@gmail.com.

2. CNRS, MNHN, UMR 7209 Archéozoologie, Archéobotanique: Sociétés, Pratiques et Environnement, 55 rue Buffon, 75231 Paris cedex 05, France. Email: antoine.zazzo@mnhn.fr.

3. $\dagger$ Deceased.

4. Université Paris 1 Panthéon-Sorbonne, UMR 7041 Archéologie et Sciences de l'Antiquité, Institut d'Art et

d'Archéologie, 3 rue Michelet, 75006 Paris, France. 


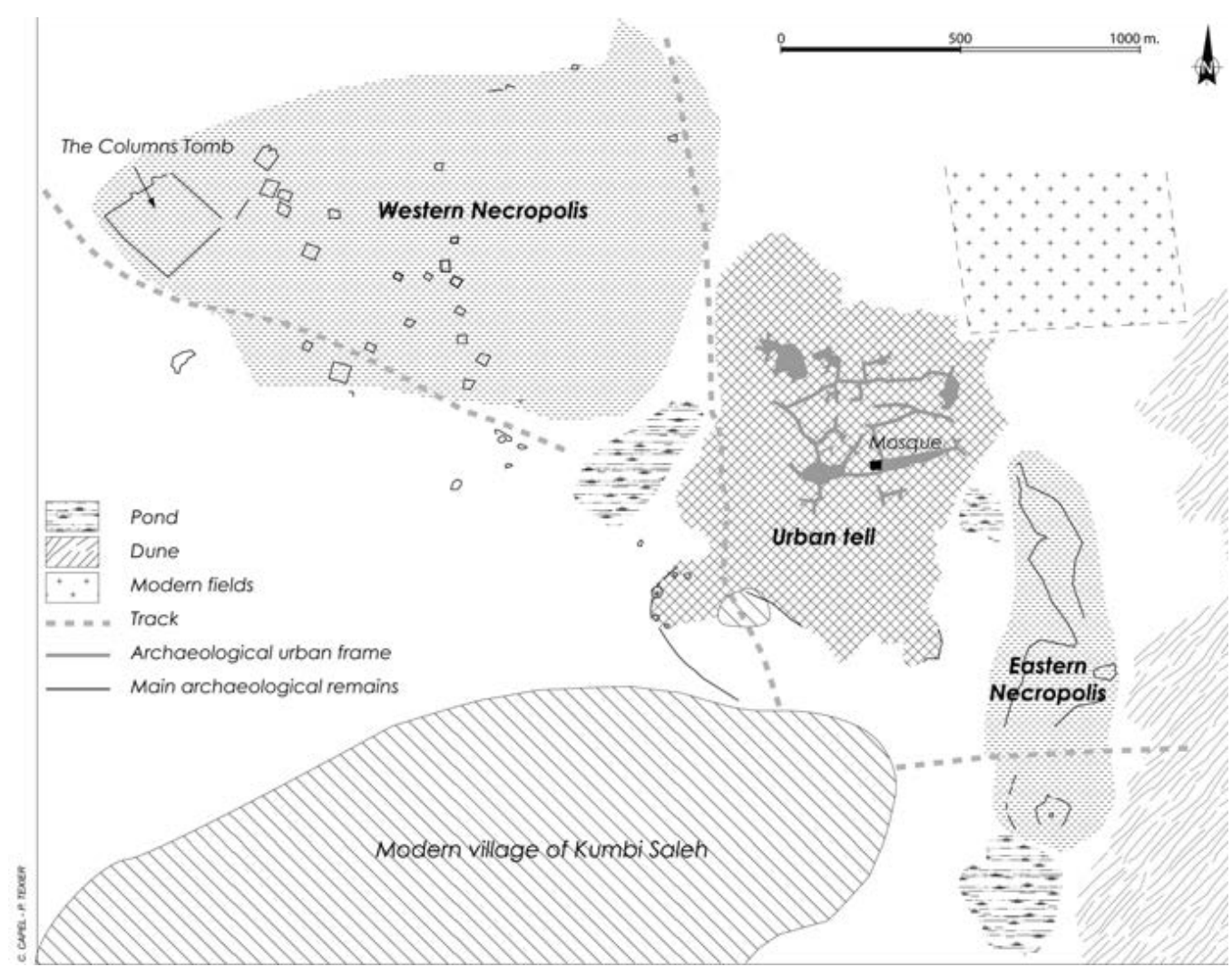

Figure 1 Map of Kumbi Saleh, based on original survey of January 2007 [Pierre Texier (INRAP) - Chloé Capel]

Following the excavations of Bonnel de Mézières, five archaeological teams have successively worked at Kumbi Saleh. These programs, especially the one supervised by Serge Robert, Denise Robert, and Jean Devisse between 1972 and 1981, have established a global chronology of the site where a settlement was identified from the 8th (or even the 5th?) century followed by a dense urban occupation that occurred between the 11th and 14th centuries, before a period of urban decline until the 17th century (Van Doosselaere 2014). The density of the urban layout on the main tell, the widespread use of a stone architecture since the 11th century, the presence of at least one mosque in Kumbi, many artifacts imported from northern areas, funerary enclosures with niches directed to east (mihrabs?), and more recently some headstones with Arabic epigraphy are all clues reflecting the significance of North African urban and social models and the likely settlement of an important Muslim community in Kumbi Saleh, as early as the 9th or 10th century (Robert 1970; Berthier 1997; Triaud 1999:262-5; Robert-Chaleix et al. 2004-2005). As a consequence, Kumbi brings together a large amount of features that would make it the Muslim city of Ghana.

Though mostly focused on the urban tell of Kumbi, archaeologists have never lost sight of Bonnel de Mezières's "Great Tomb," and since 1949, it has been renamed by Raymond Mauny the "Columns Tomb." Emptying the 1914 backfilled pits in 1949, Mauny finally documented the inner layout still preserved in the central vault by providing a sketch and some photographs (Thomassey and Mauny 1951:440-3; Mauny 1961:477). In 1972, within the framework of the program initiated by Serge Robert, Bernard Saison and Claude Richir succeeded not only in drawing an accurate map of the entire funerary complex of the Columns Tomb, whose central vault is only one element, but 
also in conducting a complementary survey between the second and fifth enclosures, including a pit with original results (Saison et al. 2004-2005). Despite its short duration - international geopolitical conditions having prevented any follow-up - the last intervention on the site in January 2007, under the supervision of Jean Polet, has also produced a number of original elements while the area of the western necropolis was subjected to an extensive evaluation by the archaeo-anthropologist Esther Gatto (Polet 2007:35-9, 51-9).

\section{A Fundamental Historical Issue: The Recurring Question of Dating of the Columns Tomb}

The plan of the Columns Tomb, which is now a largely destroyed monument (Figure 2), is nonetheless quite well documented today. It comes in the form of a $5 \times 5 \mathrm{~m}$ inner vault of pelite masonry, whose angles, aligned with the cardinal directions, were hollowed out into four niches. Each of them contained a column (also of stonework) from which the building takes its name (Bonnel de Mézières 1923:252; Thomassey and Mauny 1951:440) (Figures 3 and 4). The burial chamber, located $2 \mathrm{~m}$ below, was accessible through an entrance and a flight of steps provided on the southwest side. Bonnel discovered there three chests of large pelite slabs, positioned contiguously, vertically or flat, each chest containing the remains of an individual, head pointing to the southwest, and according to Bonnel, not containing any artifact deserving of interest (Bonnel de Mézières 1923:252-3). Topographically, from the top of a hill, the monument directly overhangs the western necropolis of Kumbi Saleh extending over an area of about 170 ha (Saison et al. 2004-2005:50; Polet 2007:20). Six roughly square concentric walls, broken up by about 30 gates, enclose an area of about 6 ha around the central vault (Saison et al. 2004-2005:52) (Figure 5). Inside this enclosed area, about 200 graves, marked by headstones, were formally located. Because of the probable superimposition of sepulchres, the number of individuals buried in the Columns Tomb enclosure may rise to nearly a thousand (Bonnel de Mézières 1923:250; Saison et al. 2004-2005:53-4; Polet 2007:39).
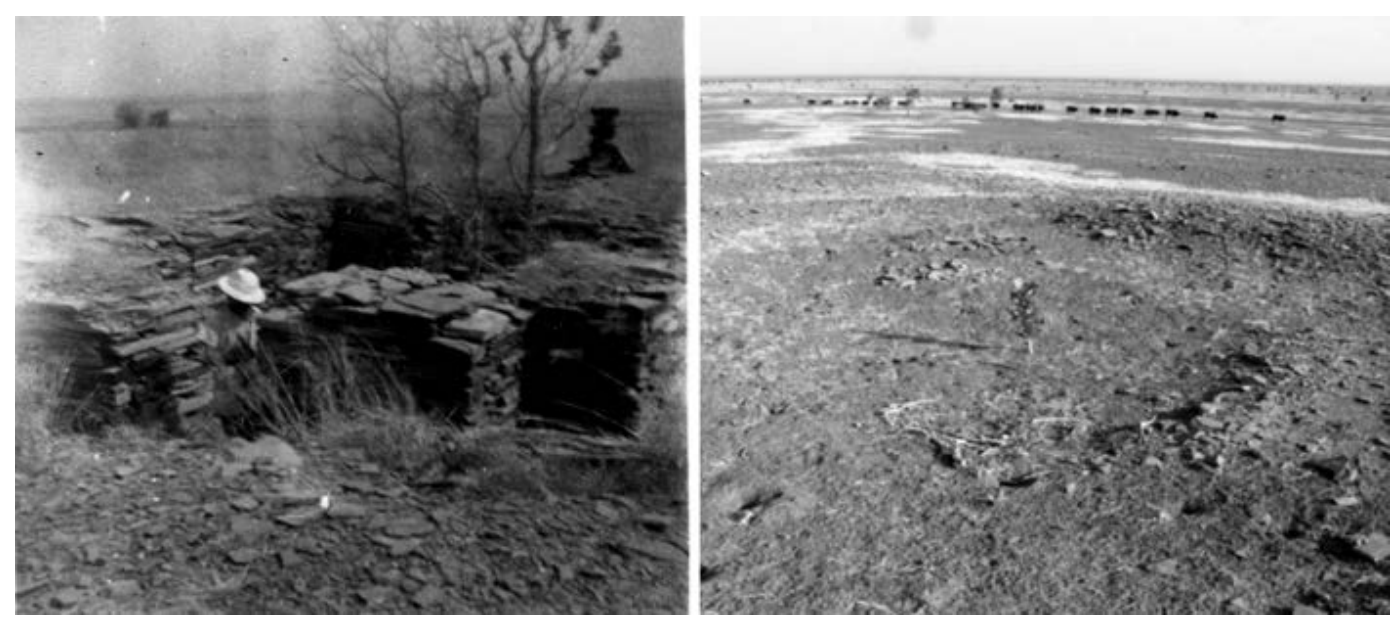

Figure 2 The inner vault of the Columns Tomb in 1949 and 2007 (Raymond Mauny, Mauny 1949:24, Figure 382; Bourahima Ouedraogo, Polet 2007:92).

Researchers today agree that the Columns Tomb is an outstanding building in the history of West Africa, unique both for its size and the nature of its layout, for which no comparable example is known. But the interpretation of the whole monument is still an issue, for a relatively detailed archaeological documentation about the structures coexists with a very meager and incomplete knowledge about the burials themselves and the individuals placed in the numerous tombs. As a consequence, the teams that succeeded one another at Kumbi Saleh since 1914 have failed to concur 

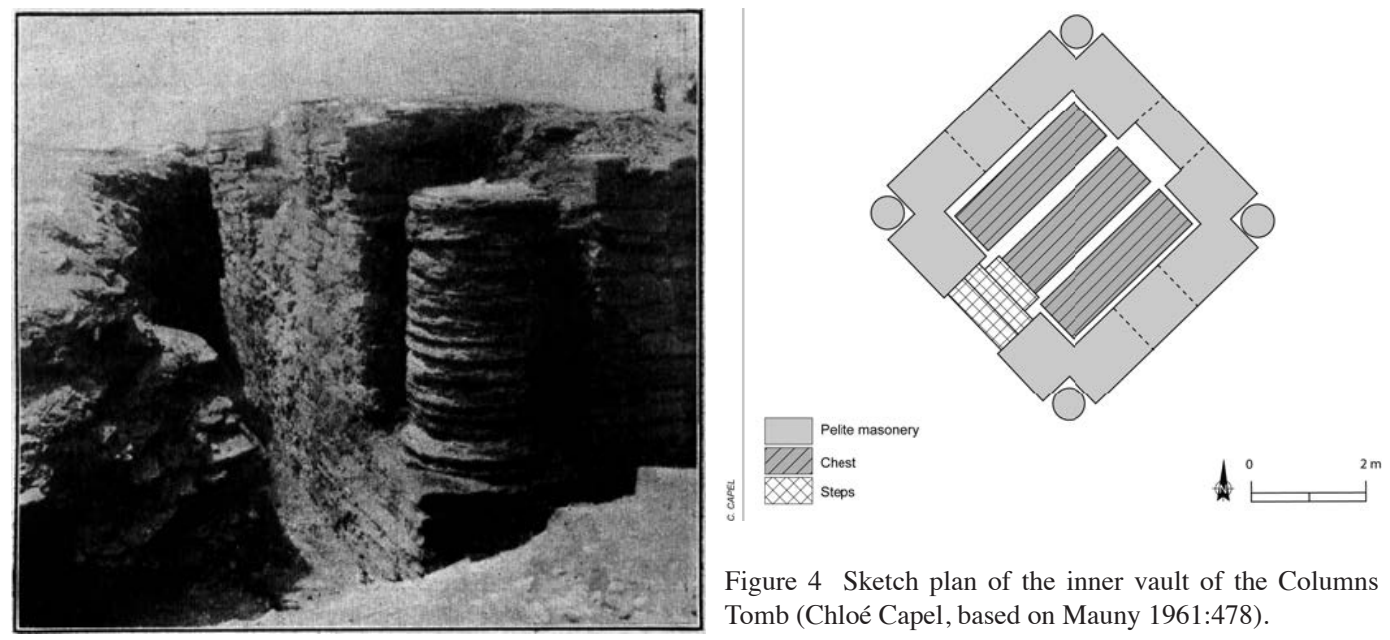

Figure 4 Sketch plan of the inner vault of the Columns Tomb (Chloé Capel, based on Mauny 1961:478).

Figure 3 The inner vault of the Columns Tomb in 1914. The columns are still in situ. This is the unique photograph of these structures (Bonnel de Mézières 1923:249).

Figure 5 Plan of the whole Columns Tomb completed in 1972 by Bernard Saison and Claude Richir (Saison et al. 2004-2005).

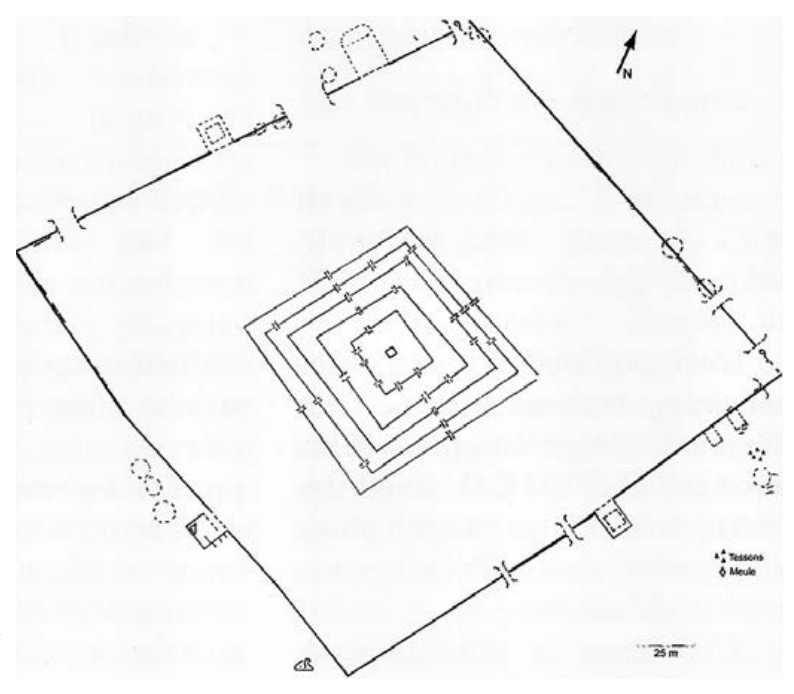

on a reliable and definitive dating of the building, a source of recurring contradictions that hinders the understanding of the monument and limits its implementation in the regional history. Through the overall chronology that has been established about Kumbi Saleh for a century, the Columns Tomb should theoretically date from the 8th (5th?) to 17th centuries, considered as post quem and ante quem termini for the development of the Sahelian city (Van Doosselaere 2014). Mauny proposed to identify the Columns Tomb as a Muslim cemetery. He dated the structure from the 12th or 13th centuries but unfortunately without specifying the arguments that led him to this conclusion (Mauny 1949:26; Thomassey and Mauny 1951:443). According to a totally opposing point of view, Saison et al. (2004-2005) dismiss outright the possibility that it might be Muslim burials because the direction of human remains, which is variable in the enclosures, would not be correct according to Islamic requirements. They asserted that the foundation of the monument would be pre-Islamic 
(i.e. pre-9th century), but that the structure would have been kept in use until about the beginning of the Muslim era, i.e. the 10th century (Saison et al. 2004-2005:60). Accordingly, in the absence of decisive arguments and because of this considerable interpretative range, an unsatisfactory millennium span of time has usually become the only chronological reference. Furthermore, the unique morphology of this monument is devoid of any element of comparison, which could be a reliable dating evidence. Whereas in the Sahel and Sahara most of the large ancient burials are mounds or megaliths, and in the Maghreb no comparable surrounding walls around kubbas are known, the morphology of the Columns Tomb has not failed to perplex researchers (Saison et al. 2004-2005:59). In the absence of new analytical elements for the last 40 years, knowledge has not advanced and the accurate date of this unique building remains unknown. Refining the commonly accepted "medieval" dating (8-14th centuries) is an absolute necessity. First, it would allow to locate this unique building into an accurate storyline as the long history of Kumbi Saleh shows different periods, with likely very different economic, social, and political implications. Secondly, it would finally allow to propose sound historical and social interpretations, which are very limited so far.

\section{Rediscovery of the Kumbi Skulls}

There is an avenue of documentation that has not yet been explored: it is the archaeological collection from the Bonnel de Mézières excavations, which probably landed in France shortly before the outbreak of the First World War. In the late 1940s, Mauny explored the reserves of the Muséum National d'Histoire Naturelle in Paris but failed to find the objects. He declared the collection lost (Mauny 1949:74; Thomassey and Mauny 1951:441). The fate of this deposit did not surface until 2008. At our request, the Musée de l'Homme in Paris unearthed from its collections a set of human bones, inventoried under the label "Kumbi - Mali"-Kumbi Saleh being formerly part of the Malian territory (former French Sudan) until the border modification in 1944 (Figure 6).

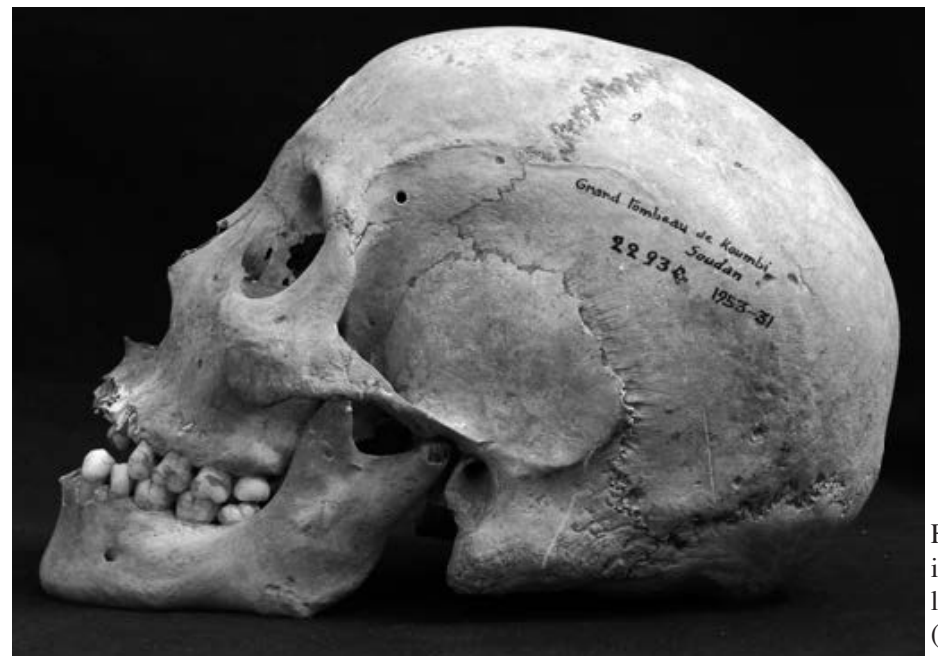

Figure 6 One of the three skulls from the inner vault of the Columns Tomb, collection of the Musée de l'Homme, Paris (Chloé Capel).

Following the opening of boxes containing the Kumbi bones in July 2009-six skulls and three long bones - the first documentary work was to collect, collate, and match up all the identifying data shared between the actual content of the lots, the inventory registers of the museum, and the historiographical sources in order to draw up inventory sheets that would be carefully documented and reliable (Table 1). With certainty, this preliminary census established the identification of those el- 
ements with some bones collected at Kumbi Saleh by the 1914 mission. The decisive arguments on which this identification is based on are two handwritten notes from the bone collection (Figure 7) and some ancient markings, directly made on the skulls: all specify the allocation of these bones to a Great Tomb, an expression of Bonnel de Mézières, dropped in the course of the 1940s in favor of Columns Tomb, Mauny's invention. In addition, the inventory lists from the Musée de l'Homme revealed that the bones had been housed in this institution, established in 1938, since at least 1953, when they were recorded in the collection register. This late inventory alone explains why Mauny, in 1949-1951, failed to find the collection. Among the bones, three skulls, labeled "Crâne de chef du Grand Tombeau de Koumbi - Soudan" ("Skull of a chief from the Great Tomb of Kumbi - Sudan"), are positively recognized as those extracted from the central vault of the Columns Tomb. A careful reading of the 1923 writings of Bonnel reveals that there was probably just one burial per chest and that, despite Bonnel's claims, the graves had not been violated before the 1914 visit.

Table 1 Copy of an extract from the inventory of the Musée de l'Homme, regarding the collection of Bonnel de Mézières and updated after our researches.

\begin{tabular}{|c|c|c|c|c|}
\hline MNHN \# & Type & Description & Country & Site \\
\hline 22934 & Cranium \& mand. & $\begin{array}{l}\text { Cranium and mandible from } 2 \text { nd chest of } \\
\text { the Great Tomb (Columns Tomb) }\end{array}$ & Mauritania & Kumbi Saleh \\
\hline 22935 & Cranium \& mand. & $\begin{array}{l}\text { Cranium and mandible from } 1 \text { st chest of } \\
\text { Great Tomb }\end{array}$ & Mauritania & Kumbi Saleh \\
\hline 22936 & $\begin{array}{l}\text { Cranium \& mand. + } \\
\text { axis }\end{array}$ & $\begin{array}{l}\text { Cranium and mandible from tomb locat- } \\
\text { ed west of Great Tomb }\end{array}$ & Mauritania & Kumbi Saleh \\
\hline 22937 & $\begin{array}{l}\text { Cranium \& mand. + } \\
\text { vertebrae }\end{array}$ & $\begin{array}{l}\text { Cranium, mandible, and } 5 \text { vertebrae, in- } \\
\text { cluding } 2 \text { axis, from a tomb located west } \\
\text { of the Great Tomb }\end{array}$ & Mauritania & Kumbi Saleh \\
\hline 22938 & Cranium \& mand. & $\begin{array}{l}\text { Incomplete cranium and mandible from } \\
\text { 3rd chest of Great Tomb }\end{array}$ & Mauritania & Kumbi Saleh \\
\hline 22939 & $\begin{array}{l}\text { Cranium \& mand. + } \\
\text { axis }\end{array}$ & $\begin{array}{l}\text { Cranium and mandible and axis from } \\
\text { tomb located north of Great Tomb }\end{array}$ & Mauritania & Kumbi Saleh \\
\hline 23673 & 2 femur +1 tibia & $\begin{array}{l}\text { Left femur and left tibia from a chest of } \\
\text { the Great Tomb; left femur from a tomb } \\
\text { located north of the Great Tomb }\end{array}$ & Mauritania & Kumbi Saleh \\
\hline
\end{tabular}

Figure 7 "3bis. Provenant du 3ème sarcophage du Grand Tombeau de Koumbi." One of the two handwritten notes of Bonnel de Mézières' lot mentionning the Great Tomb (i.e. Columns Tomb) and probably written in the late 1910 s. These notes prove the antiquity of the collection, which obviously is not Mauny's lot, collected in the early 1950s (Chloé Capel).

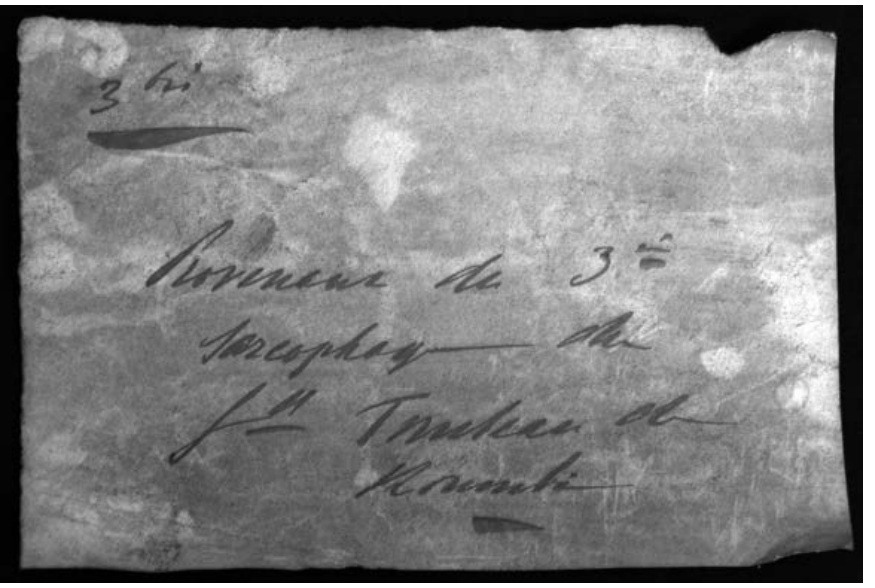


The discovery of these bones opens several new avenues of research among which ${ }^{14} \mathrm{C}$ dating was certainly the most urgent. This article provides the first direct dates for the Columns Tomb.

\section{MATERIALS AND METHODS}

Two samples were prepared for each of the three subjects from the Columns Tomb. Due to budgetary restrictions, only two of the three skulls (22938 and 22934) benefited from double dating. Arid conditions in Kumbi Saleh are detrimental to the preservation of bone collagen, the usually preferred medium for ${ }^{14} \mathrm{C}$ dating. For this reason, we decided to date the mineral (carbonate hydroxyapatite or bioapatite) fraction of bone and enamel. Work by our team for more than 30 years has demonstrated the potential of dating on bioapatite in arid environments (Saliège et al. 1995, 2013; Zazzo and Saliège 2011). Bone and enamel samples were finely ground, then immersed in a solution of acetic acid (1N) for $18 \mathrm{hr}$ under weak vacuum to remove secondary carbonates from the depositional environment and rinsed several times with distilled water. Once dried, the powders were hydrolyzed in the presence of $100 \%$ orthophosphoric acid and the extracted $\mathrm{CO}_{2}$ was sealed in a glass tube. The $\mathrm{CO}_{2}$ gases were then graphitized and measured by accelerator mass spectrometry (AMS) at the LMC14 laboratory (Saclay, France).

\section{RESULTS}

The ${ }^{14} \mathrm{C}$ ages (Table 2) vary between $835 \pm 30$ and $925 \pm 30 \mathrm{BP}$. The ages obtained on enamel and bones of the same individual (\#22934 and 22938) are not significantly different. The results demonstrate the overall good preservation of bioapatite and ensure the reliability of our results. Once calibrated, the results indicate an age between the second half of the 11th century and the late 12th century or early 13th century for these three individuals.

Table 2 List of AMS ${ }^{14} \mathrm{C}$ dates. Dates were calibrated using CALIB 6.1 (Stuiver and Reimer 1993).

\begin{tabular}{|c|c|c|c|c|c|c|c|}
\hline & MNHN & & & $\delta^{13} \mathrm{C}$ & & & \\
\hline $\mathrm{Lab} \#$ & $\#$ & Tissue & $\% \mathrm{C}$ & (VPDB, \% $)$ & ${ }^{14} \mathrm{C}$ age & $68.2 \%$ range & $95.4 \%$ range \\
\hline $\begin{array}{l}\text { P1100/ } \\
\text { SacA24640 }\end{array}$ & 22934 & Enamel apatite & 0.79 & -2.0 & $835 \pm 30$ & AD 1175-1251 & AD 1157-1265 \\
\hline $\begin{array}{l}\text { Muse 160/ } \\
\text { SacA28900 }\end{array}$ & 22934 & Bone apatite & 0.71 & -1.8 & $875 \pm 30$ & AD 1058-1215 & AD 1043-1224 \\
\hline $\begin{array}{l}\text { P1101/ } \\
\text { SacA24641 }\end{array}$ & 22935 & Bone apatite & 0.65 & -5.1 & $925 \pm 30$ & AD 1044-1155 & AD 1026-1177 \\
\hline $\begin{array}{l}\text { P1102/ } \\
\text { SacA24642 }\end{array}$ & 22938 & Bone apatite & 0.58 & -4.4 & $890 \pm 30$ & AD 1051-1208 & AD 1042-1216 \\
\hline $\begin{array}{l}\text { Muse162/ } \\
\text { SacA28902 }\end{array}$ & 22938 & Enamel apatite & 0.62 & -3.6 & $895 \pm 30$ & AD 1048-1206 & AD 1041-1214 \\
\hline
\end{tabular}

\section{DISCUSSION}

The dating of the three skulls allows us for the first time to contextualize this unique monument of Sahara, so far largely isolated from any historical or cultural context, and to place it within the framework of the ancient history of West Africa. This result represents the first step to any further interpretation of this exceptional building, the complexity of which is often underestimated. Some of these reasoning and historical approaches are considered below.

\section{Toward an Accurate Historical Timeframe}

The data suggest that the three individuals buried in the Columns Tomb all died at a similar time, limited to about a century and a half between the second half of the 11th century and the first quarter of the 13th, which is closely akin to Mauny's opinion. However, the superposition of the calibrated 
age ranges cannot decipher between hypotheses of simultaneous or staggered deaths among these three individuals. Yet, this possible chronological space in the use of the main vault of the Columns Tomb had already been highlighted by Saison and Richir in the funerary space within the concentric walls (Saison et al. 2004-2005:56). Several late transformations in the masonry of the vault, noticed by Mauny - but not yet commented on by researchers - also confirms that the place had been frequented for a long time (Mauny 1949:23-4). In this regard, it should be noted that the datings obtained from the skulls do not date the construction of the Columns Tomb but merely the deaths and the burials of its three main occupants, who can only be considered as the final phase of occupation of the inner vault. Nor do they date the numerous burials outside the vault, which could have either preceded or followed the central graves.

A dating from the 11-12th century makes this use of the vault in the Columns Tomb contemporary to the urban expansion phase of Kumbi, as identified on the main tell (Levels I and II). At that time, the first diffuse settlement on the site (inaccurately dated from the 5th to 10th century) gave way to a period of intensive construction and dense urbanization around the Grand Mosque, starting in the second half of the 11th century (Berthier 1997:28; Van Doosselaere 2014). The latter, though probably founded in the course of the 10th century, was rebuilt in a more ambitious scope, also precisely at this time (Devisse and Diallo 1993:111; Berthier 1997:29; Robert-Chaleix et al. 2004-2005:43). Thus, the burial of the three individuals of the Columns Tomb obviously accompanies a period of economic prosperity as well as a likely political affirmation of the city, to which it may be connected. Consequently, the question arises of the identity of these three characters in their possible role in the heyday of the city.

\section{Is the Columns Tomb the Grave of Some Kings of Ghana?}

The unique layout of the Columns Tomb suggests that the individuals buried in the central vault were important characters for this Sahelian city. However, the exact nature of this favored status cannot be determined with greater certainty. An interpretive leap would be to make these individuals sovereigns, and further, if we yield to the temptation of the historiographical debate that has driven the community of historians and archaeologists for over a century, to make them "Kings of Ghana." If some scholars proposed to identify Kumbi Saleh as the site (or at least one of the sites) of the capital of Ghana, as the medieval Arab geographers described it, this association is in fact far from assured and remains controversial (Triaud 1999:274-7; Masonen 2000:519-21). Whatever the link between Kumbi Saleh and Ghana, it remains a viable hypothesis that the individuals buried in the Columns Tomb may be sovereigns. Al-Bakrî (Description 327; De Slane 1913) provides precise information about the identity of two kings - literally two "Ghana" — who have exercised their authority over the Awkar (the area of Kumbi Saleh) precisely in the second half of the 11th century. Their names were Basî, who died in 455/1062, and his nephew Tankâminîn, to whom he yielded the throne. Their two reigns and deaths are contemporary to the burials of the Columns Tomb. But al-Bakrî (Description 330; De Slane 1913) also describes the funeral rites usually reserved for the Ghana. The mounds and the offerings he describes, similar to some funeral practices studied in some ancient graves in the Sahel (Desplagnes 1903, 1951), in no way reflect the remains of the Columns Tomb in Kumbi Saleh. Thus, the use of historical sources, in disagreement with the archaeological evidence, does not illuminate our understanding of the Columns Tomb, except perhaps to suggest that the Ghana would not be the one buried there. Nevertheless, we might also consider that some Ghana would have required a very individual and specific funerary rite, out with common use normally appropriated to their social status. Could it be the case of Basî, about which al-Bakrî precisely relates that he was close to Muslim population, from which he could have borrowed composite funerary practices? The question remains open. 


\section{Might the Columns Tomb be Evidence of the Almoravids' Impact South of Sahara?}

The uniqueness of the Columns Tomb makes this an archaeological unicum in the Sahel. While West Africa has revealed funerary structures equipped with enclosures as in Tegdaoust (Robert 1970:474-8), the Maghreb many-centered plan type monuments as kubbas, the Sahara some concentric structures (Paris 1995:552), and in all three regions clusters of individual burials (cemeteries), no monument, except the Columns Tomb, combines these four characteristics. In spite of obvious borrowings from local practices (as square enclosures), the morphology of this tomb also greatly differs from other graves located in the two cemeteries of Kumbi Saleh (stone mounds, simple masonry tombs, graves with Muslim steles) (Thomassey and Mauny 1951:444-5). Whatever the origin of this innovative combination may be - it may be the result of a very individual decision (of one man) or significant of collective cultural evolutions - and whether it was carried over in a short period of time (one phase of development) or is the consequence of a longer occupation (reconstruction and transformation of the structures), the monument remains an evidence of change, if not of break. It is, at least partially, contemporary of a north Saharian deep political and religious rupture, the Almoravid movement, and of its potential deployment south of the Sahara. The Almoravid movement, initiated in mid-11th century among Saharian tribes from northern Mauritania and based on a religious Sunni reform, mainly dealt with Maghreb and the shores of the Mediterranean Sea, from al-Andalus (Iberic Peninsula) to Western Ifriqiya (Tunisia) where this strong political "empire" imposed itself until the mid-12th century. But most scholars today agree that the consecutive upheavals that affected all of North Africa and the northern fringe of the Sahara were not without repercussions in the south (Semonin 1964; Moraes Farias 1967; Coulibaly 1974; Conrad and Fischer 1982, 1983; Lange 1991; Fischer 1992; Masonen and Fischer 1996). It is thus likely that the Almoravids developed a real intellectual sphere of influence beyond the territories under their control and that, even without direct military intervention, they may have helped to precipitate some cultural developments in Kumbi Saleh, particularly in the religious sphere, the spearhead of the movement. The Columns Tomb might be a reflection of this kind of change.

\section{Is the Inner Vault of the Columns Tomb a Muslim Grave?}

At the time of the Almoravids, Islam is already a familiar religion in Kumbi Saleh, as the reconstruction and the expansion of the Grand Mosque around the 11-12th century, demonstrates it. The burials of the inner vault in the Columns Tomb should be, once more, examined in the light of this religious context. According to Saison and Richir, the direction of the bodies in the inner vault is not compatible with Muslim practice (Saison et al. 2004-2005:59). Actually, this assertion is inaccurate. Indeed, Saison and Richir did not have the opportunity to directly observe the position of the chests because in 1972, they were completely buried and probably largely destroyed. Thus, their claim was based on the observation of the plan of the vault, which now appears misunderstood. Saison and Richir believed that the access door-in the axis of which the chests were installed — was located northwest, while it is in fact on the southwest side. A misreading of the ruins is the cause of this error. As a consequence, the real position of the subjects (about $135^{\circ}$ north, head southwest and not $45^{\circ}$ north, head southeast as allusively estimated by the two researchers) does not prohibit a Muslim use, as suggested by the very southern direction of the Maghreb qibla at the Almoravid and Almohad times $\left(150-160^{\circ}\right)$ or Merinid times $\left(120-130^{\circ}\right)$ (Bonine 1990:52). The direction of the mosque of Kumbi, which provides a local and contemporary point of comparison, is estimated about $90-110^{\circ}$ to the north (i.e. due east) (Polet 2007:12), a layout clearly inherited from the foundation phase of the building. It is an orientation much farther toward the north than the burials of the central vault. The latter thus are closer to the contemporary Maghreb practices than, it seems, to older local Muslim practices. Is there evidence of a link between this grave and the northern Almoravid world? One must keep in mind two additional aspects. First, the entire Columns Tomb's orientation is not 
only Muslim but also coincides with the cardinal directions, which may have no link with Islamic habits. Second, in the case of the reoccupation of an older tomb, even with new rites, the existing building inevitably determines the position of the last burials, which limits the significance of the orientation of these later graves.

\section{CONCLUSION}

The dating of the three skulls from the central vault of the Columns Tomb of Kumbi Saleh, around the 11th and 12th centuries, provides the first certain chronological conclusion for this unique monument, previously undated in the history of Western Africa. This dating gets knowledge moving again after 40 years of stagnation. Because it also establishes the authenticity of the Kumbi bones, it throws the door wide open to biometric and geochemical analyses. As a consequence, this research is the first step toward further investigation of this exceptional monument and its environment. New analyses are in progress, including additional ${ }^{14} \mathrm{C}$ dating, architectural study, and biological investigations on the bones from the central vault. These investigations will improve our understanding of this funerary complex, which is now partly dated.

\section{ACKNOWLEDGMENTS}

The following must be gratefully acknowledged for their essential contribution to this study: Philippe Mennecier and Alain Froment (MNHN - Paris), who kindly agreed to open the reserves of the Musée de l'Homme in the middle of the institution's move to Rue Buffon, and who consented to samples for analysis; Alain Person (University Paris 6) for his active participation in the interpretive work of the samples; Fabrice Melka (CNRS), who made accessible, with high availability, the personal fieldwork archives of Raymond Mauny, the starting point of this study, stored at the Bibliothèque de Recherches Africaines at the Université Paris 1 Panthéon-Sorbonne; June MacCash (MTSU) for her careful reading and precious contribution to the English manuscript. Radiocarbon measurements were obtained with the support of CNRS-InSHS, and we thank the entire team of the LMC14 for technical assistance.

This article is dedicated to the memory of Jean-François Saliège, who died suddenly and prematurely a few weeks before receiving all the anticipated datings. His work in geochemistry represents the heart of this study - the last one of his numerous contributions to the dating of African sites - which could not have been completed without his scientific abilities, his intellectual acumen, and his great human qualities that we deeply mourn.

\section{REFERENCES}

Berthier S. 1997. Recherches archéologiques sur la capitale de l'Empire de Ghana: étude d'un secteur d'habitat à Kumbi Saleh (Campagnes II, III, IV, V (1975-1976) (1980-1981)). BAR International Series 680. Oxford: Archaeopress.

Bonine M. 1990. The sacred direction and city structure: a preliminary analysis of the Islamic cities of Morocco. Muqarnas 7:50-72.

Bonnel de Mézières A. 1923. Recherche de l'emplacement de Ghana (fouilles à Koumbi et Settah). Mémoires présentés par divers savants à l'Académie de Inscriptions et Belles Lettres 13(1):227-64.

Conrad D, Fischer H. 1982. The conquest that never was: Ghana and the Almoravids, 1076. I: The external Arabic sources. History in Africa 9:21-59.

Conrad D, Fischer H. 1983. The conquest that never was: Ghana and the Almoravids, 1076. II: The local oral sources. History in Africa 10:53-78.

Coulibaly M. 1974. L'attaque de Ghana (XIe siècle). Afrika Zamani 2:55-77.

Desplagnes L. 1903. Etude sur les tumuli du Killi dans la région de Goundam. L'Anthropologie 14:151-72.

Desplagnes L. 1951. Fouilles du tumulus d'El Oualedji (Soudan). Bulletin de l'IFAN 13(4):1159-73.

De Slane W. 1913. Description de l'Afrique Septentrionale. Alger: Adolphe Jourdan.

Devisse J, Diallo B. 1993. Le seuil du Wagadu. In: Vallées du Niger. Paris: RMN. p 103-15.

Fisher H. 1992. What's in a name? The Almoravids of the 11 th century in Western Sahara. Journal of Religion in Africa 22(4):290-317.

Lange D. 1991. Les rois de Gao-Sane et les Almoravides. Journal of African History 32(2):251-75.

Masonen P. 2000. The Negroland Revisited: Discovery 
and Invention of Sudanese Middle Ages. Helsinki: Finish Academy of Science and Letters.

Masonen P, Fischer H. 1996. Not quite Venus from the waves: the Almoravid conquest of Ghana in the modern historiography of western Africa. History in Africa 23:197-231.

Mauny R. 1949. Mission dans l'Aouker et le Hodh du 19.02 aи 04.03.1949. Fieldwork notebook. Paris: Archives from the Bibliothèque de Recherches Africaines.

Mauny R. 1961. Tableau géographique de l'Ouest Africain au Moyen-Âge d'après les sources écrites, la tradition et l'archéologie. Mémoire de l'Institut Français d'Afrique Noire 61. Dakar: IFAN.

Moraes Farias PF. 1967. The Almoravids: some questions concerning the character of the movement. Bulletin de l'IFAN - Série B 29(3-4):794-878.

Paris F. 1995. Essai de classification des monuments funéraires sahariens. Bulletin de la Société Préhistorique Française 92(4):549-53.

Polet J. 2007. Mission Koumbi-Saleh (Mauritanie) Campagne 2007. Fieldwork report. Paris: Archives of the Archaeological Program of Kumbi Saleh.

Robert D. 1970. Les fouilles de Tegdaoust. Journal of African History 11(4):471-93.

Robert-Chaleix D, Robert S, Saison B. 2004-2005. Bilan en 1977 des recherches archéologiques à Tegdaoust et Koumbi Saleh. Afrique: Archéologie et Arts 3:23-48.

Saison B, Richir C, Polet J. 2004-2005. Le Tombeau à
Colonnes de Koumbi Saleh (Hodh oriental, Mauritanie). Afrique: Archéologie et Arts 3:49-62.

Saliège JF, Person A, Paris F. 1995. Preservation of ${ }^{13} \mathrm{C}^{/ 12} \mathrm{C}$ original ratio and ${ }^{14} \mathrm{C}$ dating of the mineral fraction of human bones from Saharan tombs, Niger. Journal of Archaeological Science 22(2):301-12.

Saliège JF, Zazzo A, Hatté C, Gauthier C. 2013. Radiocarbon dating in Petra: limitations and potential in semi-arid environments. In: Mouton M, Schmid SG. Men on the Rocks: The Formation of Nabataean Petra. Berlin: Logos Verlag. p 79-91.

Semonin P. 1964. The Almoravid movement in the Western Sudan. Transactions of the Historical Society of Ghana 7:42-69.

Stuiver M, Reimer PJ. 1993. Extended ${ }^{14} \mathrm{C}$ data base and revised CALIB $3.0{ }^{14} \mathrm{C}$ age calibration program. $R a$ diocarbon 35(1):215-30.

Thomassey P, Mauny R. 1951. Campagne de fouilles à Koumbi Saleh. Bulletin de l'IFAN 13:438-62.

Triaud JL. 1999. Le nom de Ghana: mémoire en exil, mémoire importée, mémoire appropriée. In: Chrétien JP, Triaud JL. Histoire d'Afrique: les enjeux de Mémoire. Paris: Khartala. p 235-80.

Van Doosselaere B. 2014. Le Roi et le Potier - Etude technologique de l'assemblage céramique de Koumbi Saleh, Mauritanie $\left(5^{e} / 6^{e}-17^{e}\right.$ siècles). Frankfurt: Africa Magna Verlag.

Zazzo A, Saliège JF. 2011. Radiocarbon dating of biological apatites: a review. Palaeogeography, Palaeoclimatology, Palaeoecology 310(1-2):52-61. 